\title{
Gardens in a postsuburban region: Community garden governance and ethos in Orange County
}

\author{
Eiji Toda ${ }^{*} *$ \\ Soka University of America \\ Edward Lowe ${ }^{b}$ \\ Soka University of America
}

\begin{abstract}
Submitted February 3, 2021 / Revised July 19 and October 11, 2021 / Accepted October 14, 2021 /
Published online February 8, 2022

Citation: Toda, E., \& Lowe, E. (2022). Gardens in a postsuburban region: Community garden governance and ethos in Orange County. Journal of Agriculture, Food Systems, and Community

Development, 11(2), 161-178. https://doi.org/10.5304/jafscd.2022.112.010
\end{abstract}

Copyright (C) 2022 by the Authors. Published by the Lyson Center for Civic Agriculture and Food Systems. Open access under CC-BY license.

\begin{abstract}
Considerable research has examined the changing values and governing approaches of urban community gardens since the nineteenth century in the United States. However, few studies exist for community gardens located in postsuburban contexts. This study reports the findings from six case studies of community gardens in southern Orange County, California, that asked, how are the themes of garden governance and an overarching garden ethos elaborated at community gardens? Our findings suggest that gardens manifest one of three governance approaches which we labeled anarchic, democratic, and corporate. In addition, we found two values frameworks or garden ethoses among

a* Corresponding author: Eiji Toda, Soka University of America. Eiji Toda is now at Portland State University; 1825 SW Broadway; Portland, OR 97201 USA; etoda@pdx.edu

${ }^{\mathrm{b}}$ Edward Lowe, Soka University of America; 1 University Drive; Aliso Viejo, CA 92656 USA; elowe@soka.edu
\end{abstract}

these gardens. One is a community ethos oriented toward realizing values promoting greater community engagement, and the other is an individualistic ethos oriented toward promoting the value of gardening as an independent activity for each gardener in their plot. We argue that just as gardens in the inner city have been sites to address urban problems, gardens in postsuburban environments might also address perceived shortcomings in postsuburban regions. Our findings also suggest that community gardens, particularly in newer suburban developments, reflect a shift in the utopian visions of postsuburban planning away from a consumerist lifestyle to a newer one that enables access to nature and sustained social connections among residents.

\section{Keywords}

Community Gardening, Postsuburban Regions, Qualitative Case Studies 


\section{Introduction}

Urban community gardening in the United States began at the end of the nineteenth century, when community gardens were created for poverty alleviation and city beautification (Lawson, 2005). Over this history, the values that lie behind urban community gardens have evolved during different periods, such as performing one's patriotic duty during wartime, and, more recently, expressing values of selfreliance, civic engagement, and sustainability. Studies have also identified motivations for community gardening such as food security, health benefits, income generation, youth education, preservation of open space, cultural preservation and expression, and sustainability (Draper \& Freedman, 2010; Lawson, 2005; McClintock \& Simpson, 2018).

Most existing studies, however, focus on community gardens in traditional urban centers that often lack green space and are densely developed, and in neighborhoods that suffer from higher rates of food insecurity, poverty, and crime. The values and governing characteristics of community gardens in newer, postsuburban cities, defined as multicentered metropolitan regions that grew out of earlier suburban regions to become culturally and economically independent from the older urban core (Kling et al., 1991), have not been investigated extensively. Community gardens in postsuburban regions merit more focused study, given increased scholarly recognition of the deceleration in economic and demographic growth in the world's largest city centers and the inevitability of new suburban and postsuburban development to accommodate the growing global urban populations (Keil, 2018; Kotkin, 2016). The present study examines community gardens in a highly urbanized postsuburban county: Orange County, California. Through the exploratory analysis of six cases, this report aims to illuminate the types of community gardens in postsuburban cities with a particular emphasis on their value orientations, which we call a "garden ethos," and their governance approaches, as these were the two dominant themes for the cases in our study.

\section{Literature Review}

\section{Community Gardens in the United States}

We begin with a brief overview of the history of community gardening in the United States. Between the 1890s and World War I, industrial cities experienced rapid growth of population, economic instability, and health issues due to the rapidly industrializing urban environment (Lawson, 2005). In response to a series of economic depressions from 1893 to 1915, social reformers began to advocate vacant-lot urban gardening programs for unemployed laborers to relieve poverty (Lawson, 2005). School gardens also emerged during this time as an educational space to teach civic involvement and good work habits (Lawson, 2005). A few decades later, civic beautification movements also attracted support from garden clubs, women's groups, and civic organizations to promote urban gardening. Although these urban gardening programs could be characterized as bottom-up movements, they were often organized by reformminded wealthy and upper-middle-income volunteers who primarily structured gardening programs with their leadership and land (Lawson, 2005).

From World War I through the Great Depression and World War II, millions of households grew food in the backyard and community gardens in response to a series of nationwide crises. War gardens during World War I encouraged urban residents of all ages to engage in gardening as a patriotic duty to ensure domestic food security and stable food provision for American soldiers overseas (Lawson, 2005). During the Great Depression, subsistence gardens and work-relief gardens provided the unemployed with a source of nutrition and income. Victory gardens during the World War II emphasized promotion of nutrition, recreation, and household quality of life rather than food security. These garden programs stressed the participation of all people regardless of socioeconomic status, "where bosses and workers, husbands and wives, and people from varied ethnic backgrounds worked shoulder to shoulder" (Lawson, 2005, p. 8). Government agencies were crucial in providing leadership and advocacy. Heavy reliance on federal support, however, led to the decline of urban community gardens when the war crisis subsided and 
government support decreased. After World War II, urban community gardens largely disappeared.

The urban gardening movement regained popularity in the 1970s, as community organizing, selfreliance, and neighborhood activism through community gardening grew in response to rising food prices, the energy crisis, racial tensions, urban decline, urban renewal projects, and increasing environmental consciousness (Lawson, 2005; Okvat \& Zautra, 2011). Unlike the gardening programs in earlier periods that heavily relied on outside civic organizations and government agencies to fund and govern the gardens, urban community gardens since the 1970s have operated primarily with grassroots control and maintenance, with little government oversight or funding. The transition to self-management obligated local gardeners to perform the responsibilities of community outreach and negotiations with city agencies and other organizations to protect their gardens from destruction to make way for other land uses (Lawson, 2005).

This history demonstrates that community gardens have been operated by different actors who governed the gardens and were oriented around different values or an overarching "gardening ethos" that developed through community gardening over time. In the first period, values of charity for the poor and unemployed were realized through community garden programs provided by wealthier urban reformers. In the second period, the state led the governance and promotion of community gardens to promote patriotic values through the democratic participation of all citizens. In the third period, grassroots garden activists took a more "anarchic" approach to garden governance by maintaining the garden themselves to promote an ethos of self-reliance and reclamation of idle land for more productive, community-oriented purposes.

More recent studies further support the evidence for these historical trends. For example, McClintock and Simpson (2018) have described the values and motivations associated with community gardens in traditional urban cores in the United States and Canada, finding six overlapping motivational frames: (1) sustainable development, with an emphasis on food quality, public health, food security, sustainability, self-sufficiency, food sovereignty, and community building; (2) a radical frame, entails social justice, food justice, food sovereignty, and reclamation of the commons; (3) a do-it-yourself (DIY) secessionist frame that involves an attempted disengagement from the dominant food system based on commodity and market relations, includes reclamation of the commons, gardening as a recreational hobby, therapeutic and rehabilitative qualities, and alternative economy or anti-capitalist exchange; (4) the educational frame, addresses educational values for both youth and adults; (5) the eco-centric frame, involves environmental and agroecological values and sustainability; (6) the entrepreneurial frame, illustrates monetary (income or profitability) values and job training or workforce development purposes.

Other recent studies highlight the more practical benefits of urban community gardening. Horst, McClintock, and Hoey (2017) describe six primary social benefits of growing food in urban areas: food access and food security enhancement, health benefits, income generation, skill building, community development, and incubation of broader efforts to challenge structural causes of inequality. Burdine and Taylor (2018) provide a brief summary of social and environmental benefits of community gardening, such as reducing crime, providing culturally meaningful food, raising real-estate values, especially in impoverished neighborhoods, offering ecosystem services such as stormwater retention and mitigation of urban heat island effect, and facilitating pollination and biodiversity. Community gardening as a way to enhance community beautification and to provide educational spaces has also persisted to the present (Lawson, 2005).

Purcell and Tyman (2019) have reported urban community gardeners' motivations to promote food justice and reclaim "the right to the city" to establish democratic space within neoliberal cities. Noting the "small but pervasive" practice of urban gardening in the United States, Lawson (2005) states, "urban gardening has been and remains an appealing approach [to improve American urban conditions] because it shows immediate results, is highly participatory, and is relatively cheap compared to other strategies" (p. 11). Poulsen et al. (2014) conducted a qualitative study that explored 
self-reported benefits of community gardening rather than objective benefits, indicating that community gardeners perceive community gardening as an "urban oasis" that provides a place to thrive and opportunities to reclaim the city and construct community (p. 73).

\section{Postsuburban Regions and Community Gardening}

Most studies frame community gardening predominantly as a phenomenon found in traditional urban cores (Horst et al., 2017; Larson, 2006; Okvat \& Zautra, 2011). Lawson (2005) suggests that gardens are currently "described as oases of green in a concrete-dominated urban world [and] [t] hus gardens appear in very urban spaces" (p. 3). Yet Lawson also acknowledges that the word "urban" in urban gardening "broadly refers to the city, its suburbs, and the urban edge" (p. 7). The 2012 American Community Garden Association (ACGA) survey results show that $73 \%$ of the community gardens were in urban areas, $19 \%$ were in the suburbs, and $8 \%$ were in rural areas (Lawson \& Drake, 2013).

This urban-suburban-rural continuum ignores the rapid emergence of postsuburban polycentric urban landscapes in many urban regions around the world from the last decades of the twentieth century to the present (Kling, Olin, \& Poster, 1991; Scott, 2019). These multicentered metropolitan regions are considered to have emerged out of earlier suburban forms, where the latter is often defined as primarily providing housing and associated services for workers who then commute to the city center for work (Kling et al., 1991). However, postsuburban regions develop their own cultural and economic independence from the urban core with which they were originally associated. Additionally, unlike the typically unplanned development of traditional suburbs, postsuburban regions are often characterized by development through master-planned communities. These planned "new city" developments are often guided by certain ideals for what developers imagine to be ideal middle-class communities, giving these planning efforts a somewhat utopian character from the perspective of the professional middle classes to include "safe" (often meaning demographically homogenous) neighborhoods, local professional employment, and family- and consumerist-oriented lifestyle amenities. For example, in Southern California, postsuburban development has tended to reflect the class-based utopian ideals found in the much earlier British Garden City Movement (Kling et al., 1991).

With the emergence of postsuburban regions, what had once been suburban regions dependent on a nearby urban core have since become the dominant site in the United States of culture, residence, and economic growth (Hayden, 2003). However, with ongoing suburban and postsuburban growth, tensions persist between the residents' desire to retain scenic nature and developer interests in converting the green landscape into more profitable suburban development (Hayden, 2003). In postsuburban regions, where population density can be orders of magnitude greater than that of traditional suburbs, these tensions over land use and preserving the scenic and natural aspects of the landscape can be intense. In addition, while postsuburban development initially promised a better life for both wealthy and low-income households, over time class, racial, and ethnic forms of polarization have increased (Scott, 2019). Furthermore, the auto-dependent postsuburban regions have also been associated with inefficient uses of resources and with large amounts of greenhouse gas emissions.

Despite these problems, suburban and postsuburban areas are expected to continue growing. Keil (2018) argues that "under conditions of current trends in technology, capital accumulation, land development and urban governance, the expected global urbanization will necessarily be largely suburbanization" (p. 9). We would add that, particularly for third-wave capitalist developments such as those associated with the information economy, postsuburban development will play a significant role in any regional urban expansion. This argument is not to dismiss the expected contributions of urbanization to societal modernization and environmental sustainability but to challenge the imagined "dichotomy of city and suburb" and to argue that re-urbanization and postsuburban development are a dual process. The growing global population that needs to be accommodated will push out existing urban residents through gen- 
trification or migration of mobile city dwellers to entirely new, postsuburban cities (Scott, 2019).

Most studies on community gardening have emphasized the benefits of the gardens and the tensions surrounding deindustrialization and gentrification in the traditional urban cores of many cities in the United States. A very different set of issues associated with community gardening are likely to be present in postsuburban regions, but what they might be has not been well explored. This study seeks to fill this gap by exploring the overarching values (i.e., garden ethoses) and governance approaches present in several postsuburban sites in southern Orange County, California.

\section{Study Site: Orange County, California}

Orange County is a mostly postsuburban county with more than three million residents, within the Los Angeles-Long Beach-Anaheim metropolitan region. Kling et al. (1991) describe Orange County's transformation over 40 years after World War II from a rural agricultural economy to a postindustrial, multicentered metropolitan region with a robust subregional economy based primarily on technology and information industries, real estate, and lifestyle consumerism. In the 1950s, as open space diminished and land values increased with post-war development, many families and war veterans emigrated from Los Angeles to Orange County as new suburban developments were constructed for workers in the aerospace industry based in Los Angeles. By the 1960s, new businesses and firms, particularly in southern Orange County, rapidly began transforming the region's economic landscape, a new pattern of development consistent with the postsuburban model. Postsuburban development of the new cities of South Orange County like Irvine, Mission Viejo, and Laguna Niguel involved a much higher degree of planning. In the 1970s and 1980s, newly arrived, internationally operated firms headquartered in Orange County increasingly globalized the region's economy (Kling et al., 1991). In the last decades of the twentieth century, through postsuburban development Orange County emerged as a multicentered metropolitan region increasingly independent of cultural and economic ties to Los
Angeles. It is also important to note that, unlike many suburban areas, new cities in southern Orange County were planned for much higher population densities, partly to help secure a better tax base. As a result, even single-family homes lack the large yards that might accommodate gardening activities in many housing tracts.

\section{Research Question}

To better understand the role of community gardens in postsuburban southern Orange County, our study is guided by the research question: how are the themes of garden governance and an overarching garden ethos elaborated at postsuburban community gardens in southern Orange County? We address this question through a qualitative comparative case study of six southern Orange County community gardens. In discussing these themes in the final section, we explore how they reflect those identified in previous studies.

\section{Methods}

To identify gardens to enroll in the study and to better understand the types and spatial distribution of community gardens in Orange County, the names and locations of forty-one community gardens in the county were identified through an online search. Based on publicly available information, they were categorized into four types: (1) grassroots, (2) municipal, (3) amenity, (4) university. Grassroots community gardens are established and maintained through grassroots organizing by local gardening enthusiasts. Municipal community gardens are owned and managed by a city. Amenity gardens are community gardens provided as an amenity service, typically by the homeowner association (HOA) in master-planned housing developments. University gardens are located within university properties, some of which are partially open to community members unaffiliated with the institution. The four categories were mapped with GIS software.

To select a sample of southern Orange County gardens for interviews and guided walking tours, we identified community gardens using a simple random selection procedure. Six gardens were ultimately enrolled in the study during the period available to the researchers (ending in mid-March 
2020 due to imposition of COVID-19 restrictions), representing $35 \%$ of gardens in southern Orange County. Table 1 shows the pseudonym names and types of the six community gardens, the year the garden was established, the number of plots, type of land ownership, the overall financial situation of the garden, the neighborhood density level, the percentage of white (non-Hispanic or Latino) neighborhood residents (based on zip code reported in U.S. Census data), and household median income for the zip code in which the garden is located. Table 2 lists the names (pseudonyms) of the interviewees for each garden.

The qualitative methods used to gather data for each of the six cases consist of semi-structured interviews and guided walking tours of each garden site with the garden supervisors, aiming to collect information about the history, values, and governance of the gardens. Semi-structured interviews were conducted with garden directors at garden sites. Regular gardeners were only invited to share their experiences, informally and spontaneously, during guided walking tours. Interviewees were invited to share the history and management of the community garden, demographics of the neighborhood and the garden users, gardener motivations to participate in community gardening, and challenges associated with maintaining the garden. The interview concluded with a guided walking tour during which the interviewees were invited to share the highlights of the garden.

At only one grassroots community garden and one amenity garden did the directors interviewed participate in gardening themselves. Interviewees

Table 1. Qualitative Research Sample Community Garden

\begin{tabular}{|c|c|c|c|c|c|c|c|}
\hline Name (Year Established) & Type & \# of Plots & $\begin{array}{l}\text { Land } \\
\text { Ownership }\end{array}$ & Density & Budget & $\begin{array}{l}\text { Percent } \\
\text { White } \\
(2017)^{a}\end{array}$ & $\begin{array}{l}\text { Median } \\
\text { Income } \\
(2017)^{b}\end{array}$ \\
\hline $\begin{array}{l}\text { Hillside Community Garden } \\
\text { (2009) }\end{array}$ & Grassroots & 53 & $\begin{array}{l}\text { Private land } \\
\text { (temporary) }\end{array}$ & High & Tight & $83.1 \%$ & $\$ 156,875$ \\
\hline $\begin{array}{l}\text { East Valley Community } \\
\text { Garden (1996) }\end{array}$ & Municipal & 73 & Public land & Medium & Tight & $58.7 \%$ & $\$ 60,218$ \\
\hline $\begin{array}{l}\text { Verde Community Garden } \\
\text { (1977) }\end{array}$ & $\begin{array}{c}\text { Municipal } \\
\text { (Senior Center) }\end{array}$ & 58 & Public land & Medium & Stable & $90.0 \%$ & $\$ 138,902$ \\
\hline $\begin{array}{l}\text { Pacific Community Garden } \\
(2000)\end{array}$ & Amenity (HOA) & 75 & Owned by HOA & Low & Stable & $65.7 \%$ & $\$ 159,504$ \\
\hline $\begin{array}{l}\text { La Paz Community Garden } \\
\text { (2016) }\end{array}$ & Amenity (HOA) & $\mathrm{N} / \mathrm{A}$ & Owned by HOA & Low & Stable & $82.8 \%$ & $\$ 151,723$ \\
\hline $\begin{array}{l}\text { Cherrywood Community } \\
\text { Garden (1995) }\end{array}$ & Amenity (HOA) & 86 & Owned by HOA & Low & Stable & $50.9 \%$ & $\$ 80,234$ \\
\hline
\end{tabular}

a County average (2017) is $41.4 \%$.

b All values in US $\$$; county median (2017) is $\$ 86,217$.

Table 2. Research Interviewees

\begin{tabular}{ll}
\hline Sample Community Gardens & Interviewees $(\mathrm{N}=9)$ \\
\hline Hillside Community Garden & Monica (founder, gardener), Angela (committee member, gardener) \\
East Valley Community Garden & $\begin{array}{l}\text { John (city officer, former garden supervisor), Maria (city officer, current garden } \\
\text { supervisor) }\end{array}$ \\
Pacific Community Garden & Evelyn (HOA service manager, garden supervisor) \\
La Paz Community Garden & Claire (private project manager) \\
Verde Community Garden & Sherry (senior center director), David (gardener) \\
Cherrywood Community Garden & Michelle (garden club president) \\
\hline
\end{tabular}


from the other gardens included HOA representatives, a project manager of a private company that ran the garden site for the HOA, and municipal workers who do not engage in community gardening themselves, limiting their experiences and perspectives to those of non-gardeners. However, interviewees' regular interactions with community gardeners, and their knowledge about the history and operational aspects of the gardens, provided useful information for the study.

\section{Findings}

Figure 1 illustrates the locations of the four types of community gardens in Orange County. Of the forty-one community gardens identified, nine were grassroots, sixteen were municipal, twelve were amenity, and four were university (Table 3). In North Orange County, municipal community gardens accounted for $58.3 \%$ of 24 community gardens. In South Orange County, amenity gardens accounted for $58.8 \%$ of 17 gardens. Thus grassroots gardens and publicly funded community gardens potentially open to all city residents are more common in the traditional suburban northern county, suggesting that a public-friendly ethos is more prevalent and accentuated in North Orange County. In contrast, privately operated gardens with limited access are more common in the postsuburban southern part of the county.

From analysis of the interviews, we identified two major dimensions that were common across the six community gardens. The first is the dimension of garden founding and governance, or the responsibility and control that garden members have for establishment and management of the garden site. We identified three garden governance approaches: (1) anarchic governance, in which grassroots activists founded the garden and relied on volunteers from among the members to manage all aspects of the garden through a self-organized community garden club effort; (2) democratic/ public governance, in which a garden is started by community enthusiasts but maintained and governed by the city recreation or parks department; (3) corporate HOA governance, in which a garden has been planned as part of the design of a housing tract without input of garden enthusiasts, and is managed by an HOA employee or outside contractor. A second dimension is the two overall ethoses of a garden: (1) a community ethos, oriented toward realizing values promoting greater community engagement, (2) an individualistic ethos, oriented toward promoting the value of gardening as an independent activity for each gardener in their plot,

\section{Figure 1. Community Garden Types and Locations in Orange County, CA}

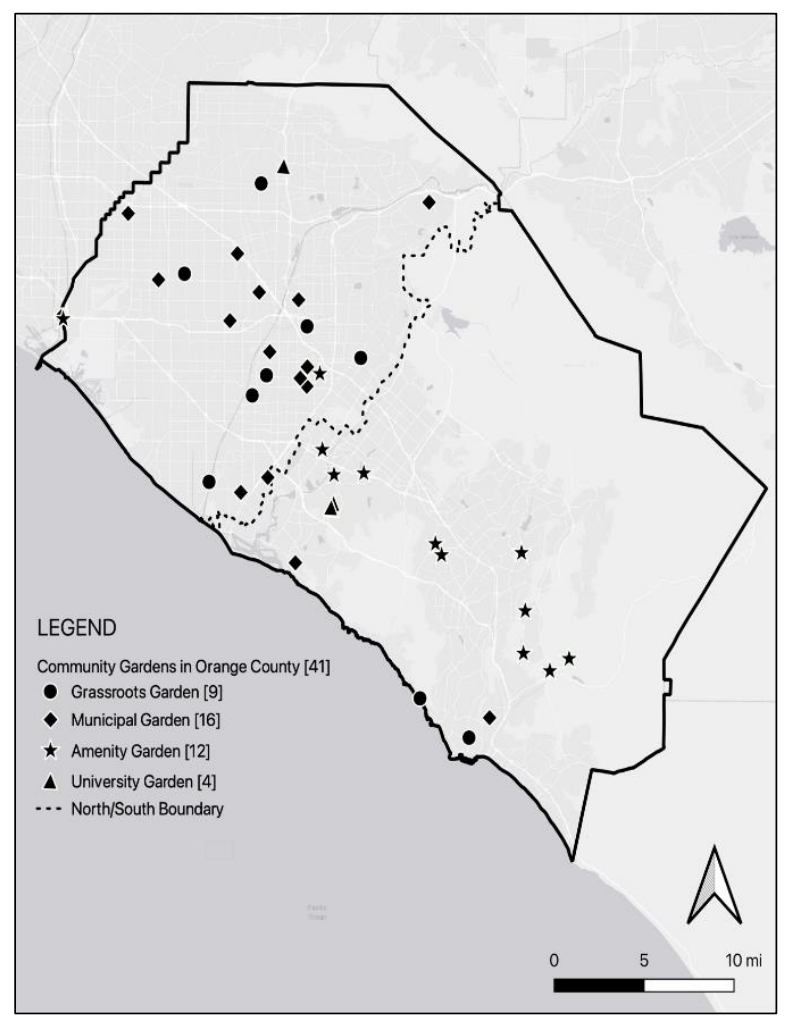

Table 3. Community Garden Types in Orange County, CA

\begin{tabular}{lccccc}
\hline & Grassroots & Municipal & Amenity & University & Total \\
\hline Total (\%) & $9(22.0 \%)$ & $16(39.0 \%)$ & $12(29.3 \%)$ & $4(9.7 \%)$ & $41(100.0 \%)$ \\
North Orange County & $7(17.0 \%)$ & $14(34.1 \%)$ & $2(4.9 \%)$ & $1(2.4 \%)$ & $24(58.5 \%)$ \\
South Orange County & $2(4.9 \%)$ & $2(4.9 \%)$ & $10(24.4 \%)$ & $3(7.3 \%)$ & $17(41.5 \%)$ \\
\hline
\end{tabular}


with an emphasis on the importance, creativity, and joy of gardening one's own plot alone. The ethos, or value framework, of a garden can exist at different poles of each dimension or be balanced in the spectrum between the two extremes. The individual garden ethos was both noted by the interviewees and physically reflected in the material configuration of each garden. The placement of each garden on the two dimensions is illustrated in Table 4.

We now elaborate on how these two dimensions are represented in the six cases.

\section{Hillside Community Garden}

Hillside community garden is on a busy street corner lot in a wealthy Orange County southern beach city. The garden site was very well maintained and designed. One enters it through a wooden handmade gate colored with red paint that welcomes visitors and gardeners alike as they enter the lush green garden area with its colorful flowers and decorations. On the day of our visit, children were playing inside the garden area as their mothers chatted nearby under a tree by a picnic table. Although its origins date to 2003 when a local vegetable seller established an illegal "guerilla garden" on what had been an unused plot of land, the citysanctioned garden site was established in 2009 on privately owned land whose owner allowed the garden organizers to use it for this purpose. Originally, the garden included 30 raised-bed planter boxes, but it expanded in 2011 to 53.

When we met with two garden board members, Monica and Angela, to find out more about the garden's origins and management and the values that gardeners realize in the garden, we quickly learned that Hillside reflects a strongly community- oriented grassroots organization. At Hillside, a membership committee interviews and approves new gardeners before accepting them to the garden and assigning a plot to ensure that they understand the level of commitment gardening requires and are ready to take care of their plots with a sense of responsibility. Gardeners felt a high level of commitment to and responsibility for the preservation and maintenance of the garden site as a whole, including securing land use rights, constructing and maintaining infrastructure, fund raising, and ensuring member adherence to garden rules and regulations. As Monica explained:

I guess [a] unique thing about this garden is that we maintain the whole property. So, [for] a lot of other gardens, I think the city maintains the property as a whole and the person who has the plot just takes care of their plot. They don't have to worry about the shrubbery around the edge or the mulch on the ground or the water system. We handle everything. So that's why we have workdays to kind of keep things looking good.

This sense of "handling everything" is one of the unique features of Hillside community garden relative to the other gardens we visited. It stood out as an excellent example of a grassroots community-oriented garden, as both gardener volunteerism and shared responsibility and shared governance of the site were strongly emphasized in the interview. It well represents the anarchic type of garden governance.

Monica and Angela also described a strong ethos of community engagement at Hillside. For example, recounting the garden's construction and

Table 4. Garden Governance and Ethos for Six SOC Gardens

\begin{tabular}{|c|c|c|c|}
\hline & & \multicolumn{2}{|c|}{ Garden Ethos } \\
\hline & & Community & Individualistic \\
\hline \multirow{3}{*}{$\begin{array}{c}\text { Garden } \\
\text { Governance }\end{array}$} & Anarchic & $\begin{array}{l}\text { Hillside CG } \\
\text { Verde CG }\end{array}$ & Cherrywood CG \\
\hline & $\begin{array}{c}\text { Public/ } \\
\text { Democratic }\end{array}$ & Verde CG & $\begin{array}{c}\text { Verde CG } \\
\text { East Valley CG }\end{array}$ \\
\hline & Corporate & La Paz CG & Pacific CG \\
\hline
\end{tabular}


the community spirit of volunteerism that supported the effort, Monica recalled:

So, all [the garden's] land was just sloping before so all that was re-graded by hand by the volunteers. And so, what we did is, we put signs up on the bulletin board "going to start building the community garden on Saturday. Show up!" And we had no idea who was going to come or how many were going to come or anything, and a whole bunch of people showed up. And they kept coming every Saturday.

Angela added:

What was neat was when we were out here working, some kids were skateboarding down the street when we were trying to place these rocks and do stuff. And he goes, "you need help?" "Yeah," and he just came in, and he wasn't a member of the garden, but the people that walked by. And you know, for me, the most valuable thing about this is the community.

The active engagement and volunteerism of both gardeners and neighbors, as well as in the garden's construction, continued as a central theme throughout the interview. The gardeners at Hillside were strongly committed to allowing non-members to also engage in the garden site. Angela noted that the garden functions as a park and a point of social connection for the community. Monica and Angela described some of the ways that they are open to the general public:

Monica: We don't fence, we don't lock the gates. People are invited to come in, whenever they want. ... I think that's one of the things that's unique about this garden. It's so open to the public and it functions as a park. So, we look at it like, you know, you could have this whole area planted in grass. And you could have a couple of picnic tables and benches all around it, or you could have planter beds and the same benches and picnic tables.
Angela: Right. We are sharing. We are sharing our space.

The community ethos is also elaborated materially at the garden site, with a small concert stage to host concerts, tables and benches, and a little free library. The planter boxes are identical in size and shape, and not as decorative as the common areas. Individual plots are not fenced or gated just like the whole garden itself being open to anyone in the neighborhood. Emphasizing the garden's value to the larger community, Monica summed up the community ethos: "I mean, they local residents] have seen how we transformed this barren lot with a chain-link fence around it into something that is an asset to the community."

\section{Cherrywood Community Garden}

Cherrywood is in a large contemporary suburban housing development that generally houses professional-class workers. The surrounding neighborhood is a picturesque-style community, with winding roads, two artificial lakes in its center, and a flood basin at its edge. At the gated entry to the garden, Michelle, the president of Cherrywood Community Garden Club, welcomed us into about an acre-size garden with 86 plots. Two wooden chairs were next to citrus trees in a garden plot owned by an old couple, and a professional carpenter's plot accommodated handmade stepped planter boxes, reflecting the unique garden vision of each gardener. The garden, located on what had been unused HOA land set aside as a flood plain, was established because of the activism of resident garden enthusiasts in 1995. Michelle described its founding:

I believe it started with one of our senior members. I think he has been here the longest ... I heard it used to be just a basin. And I guess, you know, he and a few members started talking to [the HOA], saying "Hey, why don't we utilize this? It's going to be just piles of dirt and weeds."

As with Hillside community garden, volunteerism is an important aspect of Cherrywood management. The garden club is headed by volunteers 
who perform the duties associated with membership management, rule enforcement, and event planning. The garden club is entirely financed by membership fees. However, unlike Hillside, the HOA provides the land and helps with gardener registration. While the garden club's management approach allows the gardeners to retain control of their operations and supports gardener autonomy of their plots, volunteer recruitment for leadership positions was a persistent issue. Michelle said, "It's kind of hard to recruit volunteers. A lot of people just do their garden. They don't want to do anything else. You know, it's more work without pay."

While an ethic of community involvement dominated the discussion at Hillside, Cherrywood demonstrated a more individualistic ethos. The major value framework seemed to be the reward of designing, building, and maintaining a garden plot, as well as learning to plant, tend, and harvest fruits and vegetables. A major motivation for engaging in community gardening mentioned in the interview was the sense of reward and pride that comes with the activity. Michelle said, "You know, [gardening] makes you very happy. It's like raising little kids. It prospers and it becomes something beautiful. You just feel like your kids grow into something really beautiful. And you want to eat it (laughter)." A gardener we encountered during our walking tour shared that she appreciated the relaxing qualities of the garden and the opportunities to connect with other residents from around the world. The interactions among gardeners were not necessarily oriented toward community building but rather focused on exchanging information specifically relevant to a gardener's own plot, including conditions of one's garden and tips on managing plants. Michelle summarized this point: "They really love to garden. They like big plots, and also to communicate with each other." She added:

If you go out there and basically everybody kind of knows everybody, maybe not by names, but they kind of say, you know, whoever goes in their plots, and they will compliment your plants or ask questions. And you know, there are no secrets in gardening. And most people are willing to share what they've found out.
The individualistic ethos at Cherrywood was also reflected in the material arrangement of the garden. Unlike the garden boxes at Hillside, individual garden plots at Cherrywood were fenced, with some as much as five feet high. They are closed off with small gates and locks, demarcating the community and personal realms within the community garden. Public benches or tables were absent at this garden, except for a small table outside the garden perimeter fence where gardeners can leave their excess produce for others to share.

\section{Verde Community Garden}

The Verde community garden is located on the property of a city-run municipal senior center in a wealthy coastal city in Orange County several miles to the north of Hillside. As a part of diverse amenity options, such as a fitness center and art studio, the 58-plot garden is a popular option for seniors who use the senior center. The garden was established in 1977 as a result of the activism of a resident senior who was a community garden enthusiast. Sherry, the director of the center, explained the garden's history:

This center opened up in 1977. And shortly after that, one of the seniors who liked to garden said, "Well, there's this whole piece of property, still unused. And we don't have big backyards [in our neighborhoods]. It would be nice to be able to provide garden plots for people." So, it was really one of the senior's ideas.

The land used for the senior center is owned by the city, providing the garden with secure access to the land. The city also covers most garden maintenance and operation costs. The entire garden area was well maintained and designed with concrete walkways installed during center renovation in 2008.

Garden governance at Verde combines the anarchic and the democratic/public types, the latter because the city council ultimately has oversight over the garden as part of the public senior center. The city provided the land and water for the garden site and was responsible for deciding whether the garden site would continue or be used for some other purpose, depending on the needs and wants 
of the members of the senior recreation center. However, like Hillside and Cherrywood, Verde was also generally managed by volunteers. Most of the day-to-day operations were under the control of elected officers of the garden club. Sherry described the garden club's management activities:

What the garden club does is they collect a fee upfront, and then the person uses their garden and if they don't use the garden [properly], like if they let it go to weed, then the garden club comes around and says, "I see your gardens not being maintained properly," either maintain it properly or basically they kick them out and take the next person on the waitlist. The garden club also has a monthly meeting where they'll have like a speaker come in and talk about, you know, composting or insecticides or different topics.

The ethos of Verde seemed to emphasize both a sense of community engagement and social connections, and the value of each gardener's personal enjoyment of their plot. For example, David, a gardener who spoke with us, after greeting another gardener, remarked, "That's how it is. [When we see another gardener, we say] 'Hi, how are you? How's it going?' And that's one of the beauties of a community garden. We come together from everywhere here. And this is a place that we can get to know people and it's a wonderful hobby." He explained further:

But why do we have a garden here? Because it provides an opportunity for seniors to be doing something outside their home. We don't want them sitting in front of a TV, watching TV all day long. And that's why our center exists. To get people here to be active and involved, socially interacting with other people, and it makes us live longer!

Providing a place for seniors to remain engaged in the community appeared to be a major theme. The garden, fitness facility, and art studios are placed next to each other within the property of the senior center, a physical configuration that conveys that gardening is one of diverse options for seniors to be active and to interact.

The value that gardeners find in tending creatively to their plots came through distinctly. David described this value in terms of why the garden site was so popular among senior center users:

I mean, it's always been popular because people do like to garden, and some don't have a place to do that. And here we provide them with that place to do whatever they want to do. They can grow vegetables. They can grow flowers. They can do whatever they choose that makes them feel good. So that was initially why it was brought out.

As at Cherrywood, individual plots at Verde were closed in by low fences and materially elaborated in ways suiting the tastes of each gardener. David admired the results, such as the work of the gardener whose plot was next to his own: "This is [my neighbor's garden]. I admire everything she does, and I learn from her all the time. None of us are professional gardeners. We're all volunteers or just love it. And it's a hobby." The absence of benches, tables, and common areas within the garden site also implied that garden land was dedicated for individual garden activities rather than extensive social use by the gardeners themselves or outside community members.

\section{East Valley Community Garden}

East Valley community garden is in a lower-income city where many Latino service workers reside, surrounded by the wealthier cities in the southernmost region of the county. The garden opened in 1996 on a city-owned property in response to a local garden enthusiast's request for establishing a city garden program. The city provides water and trash removal and covers about $60 \%$ of the maintenance costs. As we toured the garden, watching out for the occasional errant baseball that might fly in from the nearby field, Maria, the current garden supervisor, showed the 73 plots of four different sizes that make up the garden site. Although some plots had benches, parasols, and painted gates, these gardens were relatively less decorated compared to other gardens we visited.

Unlike the previous three gardens, gardener- 
organized community engagement and garden management are absent at East Valley community garden. The staff for the city recreation department handles all administrative aspects of the garden other than the maintenance of individual garden plots. The garden administrators are answerable directly to the city council, making East Valley the clearest representative of the public/democratic governance approach. City workers perform all the maintenance and garden management work other than individual plots, such as managing the membership and waiting lists, rule enforcement, fee collections, and weeding the walkways. The city also pays for water and trash removal. One of the former garden program directors, John, described city employee's work in the gardens:

It takes Maria time and effort to go out to look at the gardens and see if they're being kept up the way they should be. If they're not, then she has to come back and type a letter and mail it out to them. ... And sometimes you've got to go out and check if people are saying the faucets are leaking, or that, you know, the water is coming out from the hose. You've got to go check and see ... that [everything] is working.

The city was unable to organize community events for the gardeners, largely due to the limited city budget for the garden program. While touring the garden and discussing other gardens in the area, the subject of the strong community orientation and community events held at Hillside came up. Maria responded: "See, I want something like that. That's what our director was saying she'd like. ... But, you know, budget cuts. We'll see if it happens."

The ethos at East Valley community garden seemed to emphasize the realization of individual gardener needs and values, such as a sense of reward and capacity to supplement household grocery needs. John, a former garden supervisor, discussed the values that the garden supports for program participants:

I think there's a sense of pride, a little bit in growing something from scratch, a seed, and then seeing the ultimate, you know, prize, kind of, tomatoes or onions or cabbage. ... In some cases, it's a sense of urgency because they may need that food to supplement their meals. I think in a lot of cases, as Maria said, we've got a lot of retired people, and it's to organize it in the right way, so in this little portion of the section of my garden parcel, I've got onions and in this one I've got tomatoes, and this one I'm going to have cabbage. So, there's a sense of pride, not only in growing the final product, but a sense in organizing it, and keeping it organized.

Maria continued:

Some of them. They get creative, and they add like anything, like because you can if it's within our rules, you can get creative and add whatever you want. So, some people, you know, they can bring their benches and have them in there and, you know, a lot of them do. They go in there and they just relax, they sit there for a while. It's like very peaceful and that's what they do. They go there to relax.

The biggest plots available ( 29 by 20 feet) looked more like a small farm than a garden plot, allowing for a larger scale of food production. Like Cherrywood and Verde, no tables or benches intended for social interactions for gardeners were installed. Small, decorated gates and short fences also demarcated the individual garden spaces and common walkways.

\section{Pacific Community Garden}

Pacific community garden is in an unincorporated, master-planned suburban housing development that houses professional-class residents. Unlike the previous four cases, this garden with 75 individual plots was established in 2000 by the developer as a part of the housing development. The garden area is part of a larger outdoor park complex, with paved hiking trails, well-manicured lawns, and picnic tables, near a large outdoor sports complex.

We met with Evelyn, an HOA employee and the supervisor of the garden for our interview. The absence of community control over this community garden soon became clear. Under the corpo- 
rate garden governance approach, the HOA enforces rules, manages membership, sends out emails, collects fees, and maintains the common areas. Although gardeners have autonomy and active control over the configurations and crop tending in their plots, there is no garden club or event planning that facilitates community ownership of the garden. Evelyn explained:

The garden used to be run more by the residents with very little of the HOA management intervention. However, we found that the residents weren't very good at managing the money and managing the budget. We had residents accusing the people that were managing the budget of not using the money properly or of stealing money. So, at that point (sometime around 2012 or 2013), the board of directors for the HOA decided that we needed to take that over.

Evelyn noted that the HOA provides and maintains the perimeter fences and landscaping, weeding the walkways, trash cans and trash removal, garden tool sheds, and even growing rosemary on small sections of the common area. The garden hires a professional arborist and two horticulturalists who oversee the landscaping of the common areas. When we asked if the garden hosts workshops or social activities, Evelyn described the gardeners' dependence on the HOA for organizing gardener activities:

There really isn't. The reason for that is, because it's really up to them. If they come to me and say, "Hey, we like to have a meeting and create a garden club," I could help with that as far as sending emails out. I can provide them with a clubhouse at no charge. But just, we don't have staff to be able to really be able to dig in and facilitate that stuff. It would be great if we could. We just don't have anybody.

As we shifted our conversation to the values of this community garden, we learned that it was founded upon the housing tract developer's strong desire to provide a green space that would promote a sense of community and social interaction among residents. Evelyn explained:

I think it's just, you know, for a sense of community to bring people together. The developer, they are very big on community spaces. So, we have quite a long trail system. We have, I want to say, about 125 parks. We have a lot of neighborhoods where the homes face each other with a walkway in between to encourage neighbors to see each other and interact. So, this is just another way to help bring people together, doing something fun, getting them outside, bringing their kids in to learn about gardening.

For gardeners, an individualistic ethos seemed more prominent. Motivations and values seemed to range from the opportunity for outdoor exercise, access to healthy food, social interactions, expression of creativity, to educational values of teaching and learning about how to grow food. Evelyn listed the reasons why residents would start community gardening:

I think that being outside. Just probably maybe the different types of meals that they can create.... Of course, an interest in gardening and an interest in plants and for a lot of them, I think, it's just social interaction, too. They're here they're doing something that they love with other people, that also have those same interests, you know. ... I would say that probably a lot of the gardeners are interested in organic gardening, so you know I'm sure that's a big topic as well. Some people get really creative and fancy with their gardens. Other people just want to come in and garden, they don't really care to make it super fancy looking. They just want to come and garden, just kind of the basics.

Although some residents could garden at home, the community garden attracts gardeners because it is more spacious than their balconies or backyards, and allows sharing of gardening knowledge and ideas among gardeners.

Some benches for common use were available 
along the walkways in the common areas. But tables and open spaces for more extensive social use or for a garden club and community programming that would allow social interaction were absent. Some gardeners had installed chairs, tables, and parasols within their individual plots, but most plots had low fences to keep out other gardeners as well as wildlife. Some plots were highly decorative with animal decoys and pinwheels, and others were paved with stepping stones.

\section{La Paz Community Garden}

La Paz community garden is in a fairly new, wealthy suburban development built in 2013. La Paz reflects the corporate garden governance approach, and the ethos is strongly centered around the values of community development and social interaction. The garden was established in 2016 as a part of the development, or "development supported agriculture," as Claire, the contracted manager of the garden, put it. Behind a robust wooden entry gate, four long picnic tables with overhead terracing welcomed our team. The garden includes open plots for crops, raised planter beds, fruit trees, a chicken coop, and a playground for children, providing about 200 members of the garden program with access to a variety of foods and to various planned community activities. The interview began at a picnic table next to a large garden shed housing larger farming tools, an office space, and a walk-in refrigerator to store harvested produce. Unlike the other gardens we visited, there are no individually assigned plots at La Paz. Members work communally, tending crops that are planned by one of three professional farmers who work for the company that manages the HOAsponsored garden program.

When we asked why the developer decided to provide this amenity for food production, we were surprised that it was perceived as a marketing opportunity to homebuyers. Claire explained that the combination of real estate and food opportunities, such as restaurants, farmers markets, and farms and garden spaces, has become a booming trend in forward-thinking housing development. Here, we see a shift in the tendency of postsuburban regions from promoting an older, class-based, consumerist lifestyle as identified by Kling et al.
(1991) toward a newer, class-based lifestyle that promises a greater engagement in nature and opportunities to participate directly in urban agriculture. Interestingly, the relatively new planned development of which $\mathrm{La} \mathrm{Paz}$ is part does not include a large "big-box store" commercial development but does include extensive open green spaces for residents to enjoy. Claire noted that, "If you look at like, well, what's trending, people, especially our age [younger generations] are interested in where their food comes from, high-quality food organic food. And so, providing an amenity like this is extremely attractive to homebuyers." Claire also pointed out that community gardens and farms benefit developers by allowing them to save development costs and fulfill development requirements:

Additionally, it's a very affordable amenity. So, if you think about how expensive it is to build a clubhouse and a pool and a gym and maintain it, a farm can be just a unique similar amenity, right? You don't swim, you farm. You don't work out, you farm, right? And so, I think it provides the developer unique marketing affordable amenity space. And it also has stacking opportunities, so developers are required to provide a certain amount of recreation space. They're also required to provide a certain amount of green space and have a certain respect for the ecology. So, a farm kind of hits all those spots, right? The ecology, the recreation space, and the green space.

Since the garden has been established as a part of development requirements on a developer's property, the garden land is secure.

Like Pacific community garden, La Paz operates with the corporate garden governance type. The HOA contracts with a private company that provides staff to oversee all aspects of the management of La Paz. As the garden project manager, Claire also plans community events for members. Unlike the first three community gardens described above, the garden members' active role in garden management is not required.

Claire made it clear that the garden ethos at $\mathrm{La}$ Paz reflects a strong emphasis on communal work 
and community engagement rather than supporting individual gardeners to realize particular needs and values within their plot. Members participate together in various aspects of food production, generally under the direction of the garden staff. Claire described the value of this communal approach:

When we farm together with a whole space, you can harvest from all these different crops that you might otherwise not have room for. [However,] when you have a small garden plot, you don't really have the potential to do things like that. ... The other thing is individuals make a lot of mistakes. Like, I don't know if you've tried to ever grow anything, but even for me I've been growing food for almost eight years, and I still make really bad mistakes you know like, “oh!” And then if I fail, then I don't get any food. But here, there's a lot of room for mistakes to be made and a lot of chances to collaborate and share knowledge. And, say, you are part of our farm, and you go on vacation for a month, your whole community keeps the garden going whereas you have your own plot, then all of a sudden, things don't get watered, things don't get weeded, things might die, a rabbit might eat your food. So those are some of the benefits of growing food together. ... So, we grow everything together. It's all nobody's. It's all everybody's.

There are several non-farming spaces designed for social uses, such as picnic tables, playgrounds, a farm stand, and a large open space where monthly potlucks and an annual barn dance take place. Claire described the garden's collective spaces that residents can enjoy:

So, obviously one of the things that's unique about [this garden] is it was really designed to be able to entertain, right? So, you have like the grand entry, you have the terracing overhead, kind of this like big barn space that could be cleaned out for events that we want it to be. And so, it was designed with all this landscape in place. And it's all ADA accessible. You know, you could set up tables or games or any- thing sort of all over the place so that it's really accommodating for things like events.

Asked to describe the values that the members of the garden can realize, Claire presented three, derived from the communal nature of the garden's design and management. They were access to healthy food, access to therapeutic activities, and social connection and interaction:

I mean obviously, anyone who's a member gets free organic food, right? I think a lot of people are very attracted to the therapeutic quality of like coming, getting their hands in the dirt, growing something to the point of being able to eat it. ... A lot of people appreciate ... a fun way to get to know your neighbors like how else do you meet your neighbors, other than like going and shaking their hand. ... And you get to know them in a very casual setting, right? ... You know you're just out here pulling weeds and you start chitchatting about life. And that's such a natural way to connect that people find that really rewarding.

While the HOA provides other amenities and community events, so that residents can exercise and socialize, the garden's unique potential to bring residents together regularly was emphasized. What was decidedly absent at La Paz, as compared to other gardens, was a sense of being able to express oneself creatively and to invest in the personal care and nurturing of one's own crops.

\section{Discussion}

This study's research question is, how are the themes of garden governance and an overarching garden ethos elaborated at community gardens in southern Orange County? A gradient of community garden governance approaches and garden ethoses were observed, from older areas to newer housing developments. The community gardens found in relatively older developments, such as Hillside, Cherrywood, and Verde were primarily operated by community gardeners through an anarchic governance approach. Some gardens in denser areas demonstrated a democratic/public govern- 
ance approach, through which gardens are managed by municipal workers. These community gardens are located in developments established by the 1980s and 1990s. Community gardens located in developments established after the 2000s, such as La Paz and Pacific, have been founded and managed through the corporate governance approach. The near total control over garden governance by agents of the HOA reflects the substantial degree of corporate planning of the entire community.

An overall garden ethos also strongly characterized the community gardens. The main motivations and values described by the interviewees include building social connections; accessing free, healthy food; and gardening as a recreational hobby. Some gardens emphasized community development while others focused on more individual enjoyment of the garden (i.e., growing and harvesting plants in individual plots, expressing creativity, a personal hobby). Gardens with a strong individualistic ethos were characterized by less community involvement and greater privacy and individual autonomy over gardening activities. On the other hand, a community ethos promoted a collective and communal experience of the gardens, where common space is elaborated, fences are low, and community events take place frequently to facilitate social interactions.

The values of community gardens for social connections, healthy food, and as a recreational hobby found in our study support what has been found in other studies. The 2012 ACGA Community Gardening Organization Survey results show that almost all community garden organizations listed social engagement and well-being, food production and access, nutrition and improved diet, and individual personal satisfaction as a community garden's primary and secondary benefits (Lawson \& Drake, 2013). Our findings also are consistent with a qualitative study by Poulsen et al. (2014) that describes the major benefits of community gardens as building social bonds, connecting with the larger community, breaking down social barriers, and having a personal place to thrive by enhancing bodily health and cultivating psychological wellbeing (p. 73). In addition, McClintock and Simpson's (2018) first motivational framework (Sustainable Development, particularly food quality and community building) and third motivational framework (DIY secessionist, particularly reclamation of the commons, gardening as a recreational hobby, and therapeutic and rehabilitative qualities) reflect the values found in our case studies. However, other practical benefits and values of community gardens (Burdine \& Taylor, 2018; Horst et al., 2017) did not appear, perhaps because they are intended to address issues primarily at more traditional urban cores.

The history of community gardening in the United States suggests that the values and ethoses realized by gardening have been defined by those who govern the gardens. In the first period of community garden history, social reformers defined the ethos of the gardens as improvement of individual minds and alleviation of poverty. During wartime, the state defined the garden ethos as a patriotic duty, and garden activists after the 1970s defined their ethos as reclamation of urban land and anarchic self-reliance. The history of community gardens also suggests that community gardens can contribute substantially to solving problems in urban cores, such as poverty, unemployment, brownfields and urban blight, and lack of access to fresh, high-quality food. In the postsuburban context, community gardens appear to help mitigate the persistent lack of social interactions and space for shared values in postsuburban neighborhoods. In addition, as the residents of masterplanned communities lack space for creativity and personal expression due to the uniformity and strict rules placed on land use, the anarchic and public/democratic gardens that emphasize an individualistic ethos seem to provide opportunities for creativity and resident control on the individual lot level (i.e., Cherrywood, Verde, and East Valley) and the community garden site as a whole (Hillside).

Another dimension of the history of community gardens is that they become sites for the realization of different utopian ideals that gardeners and those who govern them have pursued. The images of utopia that garden advocates have pursued range from neighborhood beautification, creating ideal democratic and patriotic citizens, promoting an ethic of self-reliance, and promoting environmental sustainability and healthy communities. Our case studies reveal that some community 
gardens in the newest postsuburban developments emerged as part of private developers' utopian vision of middle-class life, which promotes sustained social connections among residents and access to nature. Both the $\mathrm{La} \mathrm{Paz}$ and Pacific community gardens were built because of the visions of their developers for creating spaces that enabled residents to foster connections to one another and productive relationships to nature through tending crops. This utopian image may reflect changing planner visions, from middle-class privacy of older developments in the 1980s and the1990s to the community orientation of newer postsuburban communities after 2000. These newer gardens are also associated with a decline of gardener control over the governance of the gardens they cultivate, and thus community gardens have become a true amenity that tends to be a site of production and consumption rather than a place to be built, managed, and sustained by the hands of gardeners themselves.

\section{Conclusion}

Our study investigated how community gardens in postsuburban regions can be characterized by a range of governance approaches and also different sets of gardening values. In some ways, the issues of garden governance and gardening ethos are like those found in other studies of gardens located in the traditional urban core. In the postsuburban environment of southern Orange County, community gardens are governed by gardener volunteers, municipal workers, or the corporate offices of the HOA. The gardens we visited were also characterized by either an individual-focused or a community-focused ethos. The realization in the gardens of different poles along these two dimensions may represent the articulation of different utopian visions for ideal middle-class communities, visions that are often at the heart of postsuburban planning and development. As one of the commentators on this article noted, how community gardens in postsuburban regions might reflect a broader effort to realize a pastoral and therapeutic vision of the United States is an interesting topic that merits further study. Historical examples of such efforts include Olmstead's design of Central Park and Boston's emerald necklace, and also the founding of the national parks. Community gardens in the postsuburban development might be considered a continuation of the earlier visions of ideals for the picturesque, remote, and healthy suburban life that informed the design of early elite suburbs in the late nineteenth century and away from the massproduction, consumerist image of suburban life that reflected post-World War II developments, such as those of the Levitt Brothers (Hayden, 2003).

Despite this study's contribution through attempting to expand the scope of community garden literature from primarily urban to postsuburban contexts, one crucial limitation is the small sample size of our cases. A larger sample and the investigation of community gardens in different postsuburban cities will help to better understand the characteristics of community gardens in postsuburban regions and their relationship to underlying problems and ideals of postsuburban development. An investigation of community gardens in other postsuburban and suburban environments could also provide additional information that could allow a more thorough comparative analysis of community gardens, and enables illumination of the unique characteristics of postsuburban community gardens compared to urban and suburban community gardens.

\section{Acknowledgments}

We would like to thank the community gardeners and garden supervisors who generously volunteered for interviews and guided walking tours. We also would like to thank the two anonymous reviewers who provided us with meaningful feedback and suggestions.

\section{References}

Burdine, J. D. \& Taylor, D. E. (2018). Neighbourhood characteristics and urban gardens in the Toledo metropolitan area: Staffing and voluntarism, food production, infrastructure, and sustainability practices. Local Environment, 23(2), 198-219. https://doi.org/10.1080/13549839.2017.1397614 
Draper, C. \& Freedman, D. (2010). Review and analysis of the benefits, purposes, and motivations associated with community gardening in the United States. Journal of Community Practice, 18(4), 458-492.

https://doi.org/10.1080/10705422.2010.519682

Hayden, D. (2003). Building suburbia: Green fields and urban growth, 1820-2000. Pantheon.

Horst, M., McClintock, N., \& Hoey, L. (2017). The intersection of planning, urban agriculture, and food justice: A review of the literature. Journal of the American Planning Association, 83(3), 277-295. https://doi.org/10.1080/01944363.2017.1322914

Keil, R. (2018). Suburban planet: Making the world urban from the outside in. Polity Press.

Kling, R., Olin, S. C., \& Poster, M. (1991). The emergence of postsuburbia: An introduction. In R. Kling, S. C. Olin, \& M. Poster (Eds.), Postsuburban California: The transformation of Orange County since World War II (pp. 1-30). University of California Press.

Kotkin, J. (2016). The buman city: Urbanism for the rest of us. Agate.

Larson, J. T. (2006). A comparative study of community garden systems in Germany and the United States and their role in creating sustainable communities. Arboricultural Journal, 29(2), 121-141.

https://doi.org/10.1080/03071375.2006.9747450

Lawson, L. J. (2005). City bountiful: A century of community gardening in America. University of California Press.

Lawson, L. J., \& Drake, L. (2013). Community Gardening Organization Survey 2011-2012. Community Greening Review, 18, 20-47.

http://agriurban.rutgers.edu/Documents/Lawson $\% 20$ and $\% 20$ Drake $\% 20$ community $\% 20$ garden $\% 20 \operatorname{survey}^{0} \% 20$ rep ort.pdf

McClintock, N., \& Simpson, M. (2018). Stacking functions: identifying motivational frames guiding urban agriculture organizations and businesses in the United States and Canada. Agriculture and Human Values, 35(1), 19-39. https://doi.org/10.1007/s10460-017-9784-x

Okvat, H. A., \& Zautra, A. J. (2011). Community gardening: A parsimonious path to individual, community, and environmental resilience. American Journal of Community Psychology, 47(3-4), 374-387. https://doi.org/10.1007/s10464-010-9404-Z

Poulsen, M. N., Hulland, K. R. S., Gulas, C. A., Pham, H., Dalglish, S. L., Wilkinson, R. K., \& Winch, P. J. (2014). Growing an urban oasis: A qualitative study of the perceived benefits of community gardening in Baltimore, Maryland. Culture, Agriculture, Food and Environment, 36(2), 69-82. https://doi.org/10.1111/cuag.12035

Purcell, M. \& Tyman, S. K. (2019). Cultivating food as a right to the city. In C. Tornaghi \& C. Certomà (Eds.), Urban gardening as politics (pp. 46-65). Routledge.

Scott, A. J. (2019). City-regions reconsidered. Environment and Planning A: Economy and Space, 51(3), 554-580. https://doi.org/10.1177/0308518X19831591 